\title{
Bacillus pumilus strain YSPMK11 as plant growth promoter and bicontrol agent against Sclerotinia sclerotiorum
}

\author{
Manoj Kaushal $^{1} \cdot$ Ajay Kumar $^{2} \cdot$ Rajesh Kaushal $^{3}$
}

Received: 28 October 2016/Accepted: 6 February 2017/Published online: 26 May 2017

(C) Springer-Verlag Berlin Heidelberg 2017

\begin{abstract}
A study was executed in a direction to attenuate Sclerotinia stalk rot (SSR) disease through biocontrol agent and also to enhance crop productivity. Culture filtrate of bacterial strain YSPMK11 inhibited growth of Sclerotinia sclerotiorum in vitro which also exhibited higher plant growth promoting attributes. Interaction studies revealed maximum (81.50\%) growth inhibition at $35^{\circ} \mathrm{C}$ and $\mathrm{pH} 7.0$ after $72 \mathrm{~h}$ incubation period with $15 \%$ culture filtrate. Based upon 16S rRNA gene sequence strain, YSPMK11 was identified as Bacillus pumilus. Furthermore, the genome of this isolate was searched for antimicrobial lipopeptide, i.e., ItuD and $\operatorname{SrfC}$ genes. The PCR amplification results showed the presence of both these lipopeptide genes in isolate YSPMK11. Iturin A as antifungal compound was identified as major components of fraction through GC/MS. In field experiments, the application of strain YSPMK11 cell suspension $\left(10^{8} \mathrm{CFU} / \mathrm{ml}\right)$ suppressed disease severity by $93 \%$ and increased curd yield by $36 \%$ which was more that of commercially used fungicide in farmer practices under mid-hills of Himachal Pradesh.
\end{abstract}

Manoj Kaushal

kaushal.mbg@gmail.com

1 Research Program, Asia, International Crops Research Institute for the Semi-Arid Tropics (ICRISAT), Hyderabad, India

2 Department of Biological Sciences, Faculty of Agriculture, Science and Technology, School of Environmental and Health Sciences, North-West University, Mafikeng Campus, 2735 Potchefstroom, South Africa

3 Department of Basic Science, Dr. Y. S. Parmar University of Horticulture and Forestry, Nauni, Solan, Himachal Pradesh 173230, India
Conclusively, our study is first to demonstrate the effect of B. pumilus strain YSPMK11 in suppression of SSR under field conditions and would be employed as an efficient biocontrol agent to replace commercial fungicides in cauliflower cropping system. In addition, the presence of both lipopeptide genes (ItuD and $S r f C)$ and iturin A in this isolate makes him potent strain for biological control application in agriculture.

Keywords Bacillus pumilus $\cdot$ Sclerotinia sclerotiorum . 16S rRNA · Disease suppression - Cauliflower production

\section{Introduction}

Sclerotinia stalk rot (SSR) caused by S. sclerotiorum (Ss) is a major disease of cauliflower (Brassica oleracea var. botrytis L.) under mid-hills conditions of Himachal Pradesh. S. sclerotiorum known as white mold is a necrotrophic pathogen having wide host range including important vegetable and oil yielding crops (Bolton et al. 2006) thus causing substantial yield losses. Cauliflower curd and stem is the primary site of infection during generative phase. Disease first appears as wet soft lesion on curd which enlarges into a watery rotten mass of tissues covered by a white silvery appearance. Affected curds causes another plant parts to wilt and later die. Cool temperature and high humidity conditions in mid-hills of Himachal Pradesh are favourable for epidemics of SSR. The standard strategies employed to overcome SSR include crop management practices such as use of clean seeds, early planting date, soil tillage, and adjustment of row width and density of plant population; however, effectiveness of these measures is very limited (Yexin et al. 2011) due to sclerotia survival in soil and high potential 
virulence. Over last few decades interest in biocontrol against SSR increased, because downfall of chemical pesticides controls the pathogen as well as their impact on environment (Saharan and Mehta 2008). Although several biocontrol agents have been reported to control SSR in different crops (Awais et al. 2008; Hu et al. 2013; Kamal et al. 2015), least information is available on biocontrol of SSR in cauliflower. In an earlier study, B. pumilus SQRN43 exhibited $68 \%$ control efficacy against $R$. solani in cucumber (Huang et al. 2012). However, there is no report in literature which demonstrated the detrimental effects caused by S. sclerotiorum and their control by B. pumilus. Therefore, the present study was designed to evaluate the efficacy of cell suspensions, cell-free culture filtrates, and broth culture in suppressing SSR and effect of microbial control agent (bacterial isolate YSPMK11) in controlling SSR at different bloom stage of cauliflower followed by enhancing the productivity of crop under mid-hills of Himachal Pradesh.

\section{Materials and methods}

\section{Isolation of bacterial strain}

Endorhizosphere samples of cauliflower plants were collected from four different naturally growing agro climatic zones of Himachal Pradesh. Each zone comprises four samples, collectively yielding 16 samples. A total of 108 bacterial strains were isolated following modified replica plating technique. Streak plate method was employed to purify the isolated strains and thus stored in nutrient agar slants at $4{ }^{\circ} \mathrm{C}$ for further screening activities. Identification of isolates was done on the basis of morphological characteristics and as per the criteria Bergey's Manual of Determinative Bacteriology.

\section{Screening of bacterial isolate}

All 108 bacterial isolates were screened for different multifarious plant growth promoting attributes. Phosphate solubilization potential was detected utilizing PVK broth. Solubilizing efficiency $E$ ( $E=$ diameter of bacterial growth/diameter of clearing zone $\times 100)$ was calculated as per the method described by Bray and Kurtz (1945). Quantitative estimation of water extractable free inorganic P (Pi) was then carried out (Dubey and Maheshwari 2011). IAA, HCN (cyanogen), and siderophore production were determined as per methods described by Costacurta et al. (2006), Bakker and Schippers (1987) and Schwyn and Neilands (1987), respectively.
In vitro antagonistic activities of bacterial isolate YSPMK11 against $S$. sclerotiorum

Based on multifarious plant growth promoting attributes, bacterial isolate YSPMK11 (showing maximum activities) was selected to study antagonistic activities against $S$. sclerotiorum. To study antifungal activity, common and locally active plant disease causing fungal species $S$. sclerotiorum was procured from the Department of Mycology and Plant Pathology, University of Horticulture and Forestry, Nauni, Solan, and maintained on malt extract agar (MEA) at $4{ }^{\circ} \mathrm{C}$.

A single colony of bacterial strain grown in LuriaBertani (LB) broth with constant shaking at $150 \mathrm{rpm}$ for $48 \mathrm{~h}$ at room temperature. Bacterial culture centrifuged at $6000 \mathrm{rpm}$ for $10 \mathrm{~min}$ and bacterial cells resuspended in phosphate buffer (100 mM, pH 7.0). Cell concentration was adjusted spectrophotometrically to $9 \times 10^{8} \mathrm{CFU} / \mathrm{ml}$ (Fernando et al. 2007). Inhibitory effect of culture filtrate of isolate was studied using agar dilution technique (Warnock 1989).

\section{Production of antifungal antibiotics}

The culture supernatant was filter sterilized and used as crude antifungal antibiotic preparation. Yeast extract malt broth (YEM) medium was used to determine antifungal antibiotic production by antagonists.

\section{Effect of inoculum concentration, time course, temperature, and pH on antifungal antibiotic production}

Inoculum concentrations 5.0, 10.0, and $15.0 \%(\mathrm{w} / \mathrm{v})$; incubation periods $(0,24,48,72,96$, and $120 \mathrm{~h})$; temperatures $\left(30,35\right.$, and $\left.40{ }^{\circ} \mathrm{C}\right)$; and $\mathrm{pH}$ in the range of 5-8 were studied consequently on antifungal antibiotic production.

\section{Molecular characterization of bacterial isolate YSPMK11}

Isolation of genomic DNA was done with CTAB method (Wahyudi et al. 2010). Amplification of 16S-rRNA gene was carried out by Polymerase Chain Reaction (PCR) using specific primer (Bf-5'-GCAAGTCGAGCGGACAGATG GGAGC-3') and (Br-5'-AACTCTCGTGGTGTGACGG GCGGTG-3') which yielded 1375 bp DNA fragment. PCR was carried out; all PCR products were purified using Real Genomic DNA Extraction Kit and sequenced using ABI 310 (Perkin Elmer, USA). Similarity of each 16S-rRNA sequence was aligned against GeneBank database sequences using BLASTN program. The query sequence was aligned with ClustalW program for constructing a 
phylogenetic tree and comparison was done with those of other phylogenetically close microbial relatives.

\section{Amplification of lipopeptide genes}

The genomic DNA of isolate YSPMK11 was subjected for the identification of two lipopeptide genes, i.e., surfactin $(s r f C)$ and iturin A (ituD), as described earlier by Gond et al. (2015). The primer sequences used were: ItuDlF (GATGCGATCTCCTTGGATGT), ItuDIR (ATCGTCA TGTGCTGCTTGAG), Sur3F (ACAGTATGGAGGCAT GGTC), and Sur3R (TTCCGCCACTTTTTCAGTTT). PCR amplification of ituD gene yielded 647 bp fragment, whereas PCR amplification of $s r f C$ gene yielded $441 \mathrm{bp}$ DNA fragment. The PCR condition used for the amplification of the genes includes the initial denaturation at $95{ }^{\circ} \mathrm{C}$ for 5 min followed by 30 cycles, which consisted of denaturation at $95{ }^{\circ} \mathrm{C}$ for $1 \mathrm{~min}$, annealing at $54.5^{\circ} \mathrm{C}$ for $1 \mathrm{~min}$, and extension at $72{ }^{\circ} \mathrm{C}$ for $1 \mathrm{~min}$, and final extension was carried out at $72{ }^{\circ} \mathrm{C}$ for $10 \mathrm{~min}$. The PCR product was resolved in $2 \%$ agarose gel for $2 \mathrm{~h}$ using $100 \mathrm{bp}$ ladder.

\section{Identification of antifungal compounds}

HPLC (VARIAN Prostar 218, USA) equipped with a Pursuit Rs-5u-C18 column $\left(150 \times 21.2 \mathrm{~mm}^{2}\right)$ was used to separate cell-free culture filtrates. Prior to HPLC injection, extracts in methanol were filtered through a $0.2 \mu \mathrm{m}$ PTFE Acrodisc CR syringe filter (Pall Corp., East Hills, NY). Gradient conditions were used with methanol $/ 0.05 \%$ trifluoroacetic acid-solvent A (Sigma-Aldrich) and water/ $0.05 \%$ trifluoroacetic acid-solvent $\mathrm{B}$ at $1 \mathrm{ml} / \mathrm{min}$ and $A / B$ ratios of 10:90, 100:0, and 100:0, with run time of 0, 30, and 33 min, respectively (Pryor et al. 2006; Li et al. 2012). Samples were eluted at a flow rate of $1 \mathrm{ml} / \mathrm{min}$, and the elution profile was monitored with UV detector at $210 \mathrm{~nm}$. Fractions obtained from semi-preparative HPLC were evaporated with an $\mathrm{N}_{2}$ stream and dissolved in $\mathrm{CH}_{3} \mathrm{OH}$ for gas chromatography/mass spectrometry (GC/MS) analysis.

\section{Bioassay of lipopeptide}

Bioassay was performed using well diffusion method in which methanol extract of $100 \mu \mathrm{l}$ lipopeptides was tested against S. sclerotiorum (Meena et al. 2014). Malt extract agar (MEA) plates were incubated at $30{ }^{\circ} \mathrm{C}$ in inverted position, and after 3 days, growth inhibition (\%) was calculated by the following formula:

Growth inhibition $(\%)=(\mathrm{DC}-\mathrm{DT}) / \mathrm{DC} \times 100$ where DC, diameter of control; and DT, diameter of fungal colony with treatment.

\section{Biocontrol efficacies of bacterial isolate YSPMK11 under field conditions}

Based upon results obtained from in vitro, biocontrol efficacy of bacterial isolate YSPMK11 against S. sclerotiorum, it was evaluated under field conditions to replace heavy chemicals/fungicides load on soil without deteriorating crop productivity. Cauliflower seeds were seeded in pots containing sterilized soil with methyl bromide for nursery preparation before transplantation to main field. Field trials were quadruplicated (two at Regional Horticultural Research Station, Kullu, and two at Dr. Y. S. Parmar University of Horticulture and Forestry, Nauni, Solan) during 2010-2011. The experiment was conducted in field situated at $32^{\circ} \mathrm{N}$ latitude and $77^{\circ} \mathrm{E}$ longitude with following treatments, $\mathrm{T}_{1}$ (uninoculated control), $\mathrm{T}_{2}$ (YSPMK11-50\% bloom), $\mathrm{T}_{3}$ (YSPMK11-30\% and 50\% bloom), $\mathrm{T}_{4}$ (YSPMK11-30\% bloom), $\mathrm{T}_{5}$ (carboxamide), $\mathrm{T}_{6}$ (benomyl), $\mathrm{T}_{7}$ (vinclozolin), $\mathrm{T}_{8}$ (tebuconazole), $\mathrm{T}_{9}$ (thiophanate methyl), and $\mathrm{T}_{10}$ (iprodione) arranged in randomized complete block design (RCBD) replicated thrice with plot size of $5 \times 5 \mathrm{~m}$ in every trial. Fungicide treatments (seed treatment and soil drench at $1.25 \mathrm{~g} / \mathrm{L}$ ) were done at 30 and $50 \%$ bloom stage (singly in $\mathrm{T}_{2}$ and $\mathrm{T}_{4}$; twice in $\mathrm{T}_{3}$ plot). $72 \mathrm{~h}$ old bacterial culture was grown in $10 \%$ nutrient broth for the preparation of bacterial inoculum and a final concentration of $9 \times 10^{8}$ $\mathrm{CFU} / \mathrm{ml}$ was made. Before nursery sowing seed treatment were given at this concentration for $30 \mathrm{~min}$ at $1 \mathrm{ml} / \mathrm{seed}$. Furthermore, $72 \mathrm{~h}$ old bacterial cultures were grown in nutrient broth at $30{ }^{\circ} \mathrm{C}$ in an orbital shaker $(150 \mathrm{rev} / \mathrm{min})$ for $24 \mathrm{~h}$. Cultures were then centrifuged at $6000 \mathrm{rpm}$ for $20 \mathrm{~min}$ in $50 \mathrm{ml}$ sterile plastic tubes. Pellets were resuspended in nutrient broth again to obtain a final concentration of $9 \times 10^{8}$ $\mathrm{CFU} / \mathrm{ml}$. The liquid cultures of isolate were then used for bacterial inoculations as soil drench at 30 and $50 \%$ bloom stage (singly in $\mathrm{T}_{2}$ and $\mathrm{T}_{4}$; twice in $\mathrm{T}_{3}$ plot) at $10 \mathrm{ml} / \mathrm{plant}$. The incidence of SSR was determined based on the percentage of stems with disease symptoms among 20 randomly selected cauliflower plants from each treatment plots. Disease severity and control efficacy were calculated as follows (Anonymous 2000):

Disease severity $=\left[\sum(\right.$ The number of diseased plants in this index $\times$ Disease index)/ (Total number of plants investigated $\times$ The highest disease index) $] \times 100 \%$. 
Control efficacy $=[($ Disease severity of control

- Disease severity of treated group)/

Disease severity of control] $\times 100 \%$.

\section{Results}

\section{Bacterial isolation}

Presumptive identification of all 108 rhizobacterial isolates were done on the basis of Bergey's Manual of Determinative Bacteriology which presented strain as circular colonies having entire margin, Gram-positive, short rods, non-motile with cream pigment which matched to genera Bacillus.

\section{Screening of bacterial isolate}

When subjected to screening activities, it was found that among all the 108, only the rhizobacterial isolate YSPMK11 (Bacillus spp.) showed halo zone around its colony on Pikovskaya agar plates indicating the P solubilization. Maximum solubilization efficiency (183.60\%) showed on 4th day of incubation which started to decrease from 5th day onwards. Furthermore, this strain was tested for quantitative estimation of phosphate solubilization and showed maximum solubilized $\mathrm{P}$ (156.3 ppm) after $24 \mathrm{~h}$ of incubation.

The rhizobacterial isolate YSPMK11 (Bacillus spp.) also displayed higher IAA, HCN, and siderophore production. Development of pink colour with and without addition of tryptophan in culture broth was observed in the cell-free supernatant. Higher concentration of IAA $(30.67 \mu \mathrm{g} / \mathrm{ml})$ was produced in the presence of $3 \mathrm{mg} / \mathrm{ml}$ tryptophan. In the presence of glycine and $\mathrm{FeCl}_{3}$, the deep brown colour of filter paper was observed, giving a clear indication of $\mathrm{HCN}$ production by isolate YSPMK11. A bright zone $(17.56 \mathrm{~mm})$ of yellowish colour around the bacterial colony on Chrome-azurol-S (CAS) medium was produced by isolate YSPMK11 (Bacillus spp.) which indicate the production of siderophore. Quantitative analysis revealed that isolate YSPMK11 (Bacillus spp.) produced $57.63 \%$ siderophore unit as well as higher $\left(59.38 \times 10^{5} \mathrm{cfu} / \mathrm{ml}\right)$ viable count after $72 \mathrm{~h}$ of incubation.

\section{In vitro antagonistic activities of bacterial isolate YSPMK11 (Bacillus spp.) against $S$. sclerotiorum}

Inhibition zone ranged from 20.2 to $22.4 \mathrm{~mm}$ for S. sclerotiorum. Antifungal antibiotic activity of isolate YSPMK11 (Bacillus spp.) tested against S. sclerotiorum by culture filtrate (5-15\%) method. The results showed that culture filtrate exhibited inhibition zone against $S$. sclerotiorum which ranged from 20.2 to $22.4 \mathrm{~mm}$.

\section{Effect of inoculum concentration}

Increase in concentration of culture filtrate from 5 to $15 \%$ increased percent growth inhibition with maximum of $81.50 \%$ (Table 1). The interaction studies revealed $86.71 \%$ growth inhibition (15\% CF) after $72 \mathrm{~h}$ incubation. Thus, $15 \%$ inoculum was used for further experimentation.

\section{Duration of incubation period}

Antifungal antibiotic production was monitored for $120 \mathrm{~h}$ in nutrient broth (Table 2). The antifungal antibiotic activity increased gradually up to $72 \mathrm{~h}$ with maximum (60.20\%) growth inhibition of S. sclerotiorum later followed a decreasing trend. Results showed that $15 \%$ culture filtrate $(\mathrm{CF})$ showed more mean percent growth inhibition (62.74\%) as compared to 5\% culture filtrate $(48.44 \%)$. The

Table 1 Effect of inoculum concentration of isolate YSPMK11 on antifungal antibiotic activity against S. sclerotiorum

\begin{tabular}{|c|c|c|c|c|c|}
\hline \multirow[t]{2}{*}{ Sample } & \multirow[t]{2}{*}{ Sample details } & \multicolumn{3}{|c|}{ Antifungal antibiotic activity (\% growth inhibition) } & \multirow[t]{2}{*}{ Mean } \\
\hline & & $5 \%$ & $10 \%$ & $15 \%$ & \\
\hline Control & MEA & $0.00(1.00)$ & $0.00(1.00)$ & $0.00(1.00)$ & $0.00(1.00)$ \\
\hline \multirow[t]{3}{*}{ Test } & $\mathrm{MEA}+\mathrm{CF}(5 \%)$ & $65.08(8.12)$ & $75.94(8.77)$ & $78.76(8.93)$ & $73.26(8.60)$ \\
\hline & $\mathrm{MEA}+\mathrm{CF}(10 \%)$ & $73.90(8.65)$ & $77.53(8.86)$ & $82.93(9.16)$ & $78.12(8.89)$ \\
\hline & $\mathrm{MEA}+\mathrm{CF}(15 \%)$ & $77.34(8.85)$ & $80.43(9.02)$ & $86.71(9.36)$ & $81.50(9.07)$ \\
\hline Mean & & $54.08(6.65)$ & $58.48(6.91)$ & $62.10(7.11)$ & \\
\hline
\end{tabular}

Figures in parentheses are square root transformed values

Least square difference $(\mathrm{LSD})(T)=1.23 \mathrm{LSD}(I)=1.06 \mathrm{LSD}(T \times I)=2.12$

Values are the mean of three replications

$M E A$ malt extract agar 
Table 2 Effect of incubation period on antifungal antibiotic activity of isolate YSPMK11 against S. sclerotiorum in nutrient broth

\begin{tabular}{lllllllll}
\hline Sample & Sample details & \multicolumn{2}{l}{ Antifungal antibiotic activity $(\%$ growth inhibition) } & \multicolumn{2}{c}{ Mean } \\
\cline { 3 - 7 } & & $0 \mathrm{~h}$ & $24 \mathrm{~h}$ & $48 \mathrm{~h}$ & $72 \mathrm{~h}$ & $96 \mathrm{~h}$ & $120 \mathrm{~h}$ \\
\hline Control & MEA & $0.00(1.00)$ & $0.00(1.00)$ & $0.00(1.00)$ & $0.00(1.00)$ & $0.00(1.00)$ & $0.00(1.00)$ \\
Test & MEA + CF (5\%) & $0.00(1.00)$ & $14.47(3.92)$ & $57.86(7.67)$ & $73.26(8.61)$ & $72.81(8.59)$ & $72.21(8.55)$ & $48.00(1.00)$ \\
& MEA + CF (10\%) & $0.00(1.00)$ & $34.65(5.96)$ & $68.78(8.35)$ & $82.85(9.15)$ & $82.33(9.12)$ & $81.92(9.10)$ & $58.42(7.11)$ \\
& MEA + CF (15\%) & $0.00(1.00)$ & $47.25(6.94)$ & $75.82(8.76)$ & $84.72(9.24)$ & $84.55(9.25)$ & $84.09(9.22)$ & $62.74(7.40)$ \\
Mean & & $0.00(1.00)$ & $24.09(4.45)$ & $50.62(6.44)$ & $60.20(7.00)$ & $59.92(6.99)$ & $59.56(6.96)$ & \\
\hline
\end{tabular}

Figures in parentheses are square root transformed values

$\operatorname{LSD}(T)=0.96 \operatorname{LSD}(I)=1.18 \operatorname{LSD}(T \times I)=2.37$

Values are the mean of three replications

$M E A$ malt extract agar

Table 3 Effect of temperature on antifungal antibiotic activity of isolate YSPMK11 against $S$. sclerotiorum

\begin{tabular}{|c|c|c|c|c|c|}
\hline \multirow[t]{2}{*}{ Sample } & \multirow[t]{2}{*}{ Sample details } & \multicolumn{3}{|c|}{ Antifungal antibiotic activity (\% growth inhibition) } & \multirow[t]{2}{*}{ Mean } \\
\hline & & $30^{\circ} \mathrm{C}$ & $35^{\circ} \mathrm{C}$ & $40^{\circ} \mathrm{C}$ & \\
\hline Control & MEA & $0.00(0.00)$ & $0.00(0.00)$ & $0.00(0.00)$ & $0.00(0.00)$ \\
\hline \multirow[t]{3}{*}{ Test } & $\mathrm{MEA}+\mathrm{CF}(5 \%)$ & $39.03(38.62)$ & $82.50(65.43)$ & $36.29(37.02)$ & $52.61(47.03)$ \\
\hline & $\mathrm{MEA}+\mathrm{CF}(10 \%)$ & $40.93(39.75)$ & $89.79(71.38)$ & $42.97(40.93)$ & $57.90(50.69)$ \\
\hline & $\mathrm{MEA}+\mathrm{CF}(15 \%)$ & $46.39(42.93)$ & $91.47(73.03)$ & $51.45(45.83)$ & $63.10(53.93)$ \\
\hline Mean & & $31.59(30.33)$ & $65.94(52.46)$ & $32.68(30.95)$ & \\
\hline
\end{tabular}

Figures in parentheses are arc sine transformed values

$\operatorname{LSD}(T)=3.55 \operatorname{LSD}(I)=3.07 \operatorname{LSD}(T \times I)=6.13$

Values are the mean of three replications

$M E A$ malt extract agar

Table 4 Effect of $\mathrm{pH}$ on antifungal antibiotic activity of isolate YSPMK11 against S. sclerotiorum

\begin{tabular}{|c|c|c|c|c|c|c|}
\hline \multirow[t]{2}{*}{ Sample } & \multirow[t]{2}{*}{ Sample details } & \multicolumn{4}{|c|}{ Antifungal antibiotic activity (\% growth inhibition) } & \multirow[t]{2}{*}{ Mean } \\
\hline & & pH 6 & $\mathrm{pH} 7$ & $\mathrm{pH} 8$ & pH 9 & \\
\hline Control & MEA & $0.00(0.00)$ & $0.00(0.00)$ & $0.00(0.00)$ & $0.00(0.00)$ & $0.00(0.00)$ \\
\hline \multirow[t]{3}{*}{ Test } & $\mathrm{MEA}+\mathrm{CF}(5 \%)$ & $51.67(45.96)$ & $71.60(57.80)$ & $37.02(37.43)$ & $16.91(23.88)$ & $44.30(41.27)$ \\
\hline & $\mathrm{MEA}+\mathrm{CF}(10 \%)$ & $59.76(50.63)$ & $75.08(60.07)$ & $44.85(42.04)$ & $32.64(34.84)$ & $53.08(46.90)$ \\
\hline & $\mathrm{MEA}+\mathrm{CF}(15 \%)$ & $67.26(55.10)$ & $83.26(65.86)$ & $56.97(49.01)$ & $38.08(38.10)$ & $61.39(52.02)$ \\
\hline Mean & & 44.67 (37.92) & $57.48(45.93)$ & $34.71(32.12)$ & $21.91(24.21)$ & \\
\hline
\end{tabular}

Figures in parentheses are arc sine transformed values

$\operatorname{LSD}(T)=2.38 \operatorname{LSD}(I)=2.38 \operatorname{LSD}(T \times I)=4.75$

Values are the mean of three replications

MEA malt extract agar

interaction studies revealed maximum $(84.72 \%)$ growth inhibition at $72 \mathrm{~h}$ incubation with $15 \% \mathrm{CF}$. Thus, $72 \mathrm{~h}$ incubation was selected as the best time course for antifungal antibiotic production.

\section{Variation of temperature and $\mathrm{pH}$}

In the present study, it was observed that percent growth inhibition increased with increase in temperature from 30 


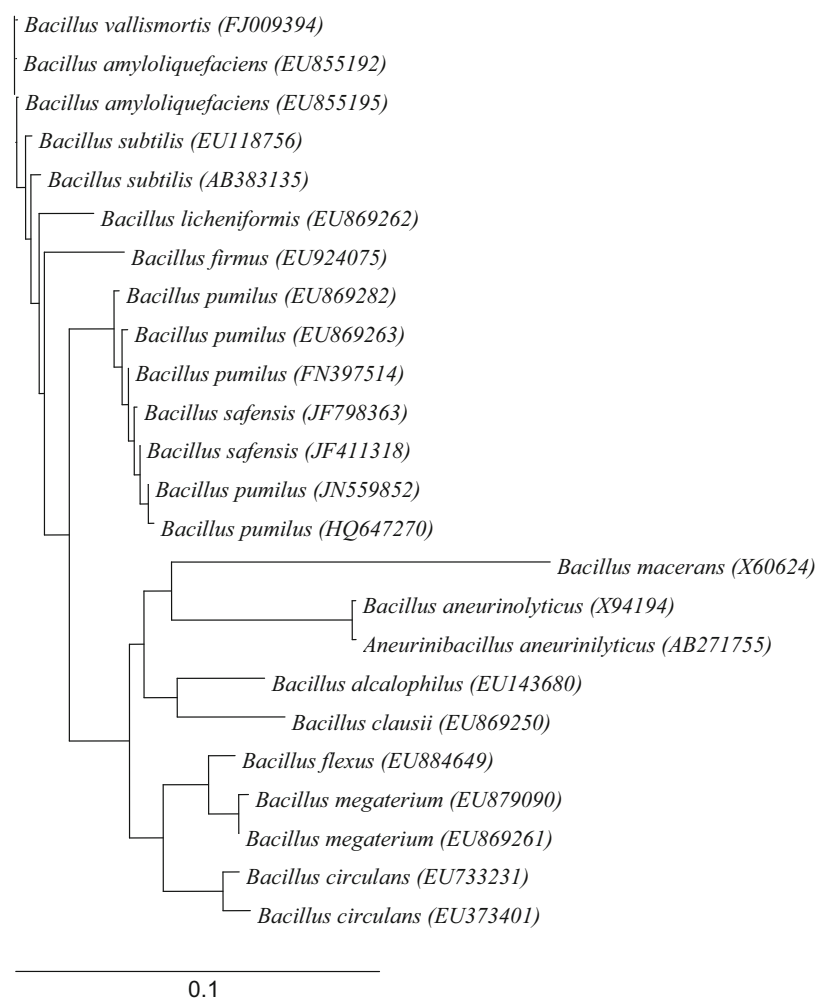

Fig. 1 Phylogenetic tree constructed by neighbor-joining method derived from analysis of the $16 \mathrm{~S}$ rRNA gene sequences of native isolate YSPMK11 and related sequences

to $35^{\circ} \mathrm{C}$; however, further increase in incubation temperature $\left(40{ }^{\circ} \mathrm{C}\right)$ adversely affected antibiotic production and growth inhibition of tested fungus (Table 3 ). Increase in $\mathrm{pH}$ from acidic towards neutral increased percent growth inhibition from 44.67 to $57.48 \%$ (Table 4). The maximum percent growth inhibition displayed at temperature of $35{ }^{\circ} \mathrm{C}$ at $\mathrm{pH} 7$ with $15 \% \mathrm{CF}$.

\section{Molecular characterization of isolate YSPMK11}

Designed primers were used successfully for amplification of 16S rDNA from bacterial isolate YSPMK11 which yielded amplicon of expected size, i.e., $\sim 1375 \mathrm{bp}$. PCR product was eluted from gel and sequenced using PCR primers used for amplification. Blasting of 16S rRNA sequence of Bacillus isolate YSPMK11 showed 99\% homology with $B$. pumilus. Dendogram based on phylogenetic analysis presented in Fig. 1 showed that Bacillus isolate YSPMK11 is clustered with $B$. pumilus. The sequence of respective isolate was submitted to the National Center for Biotechnology Information (NCBI) under accession No. JN559852.

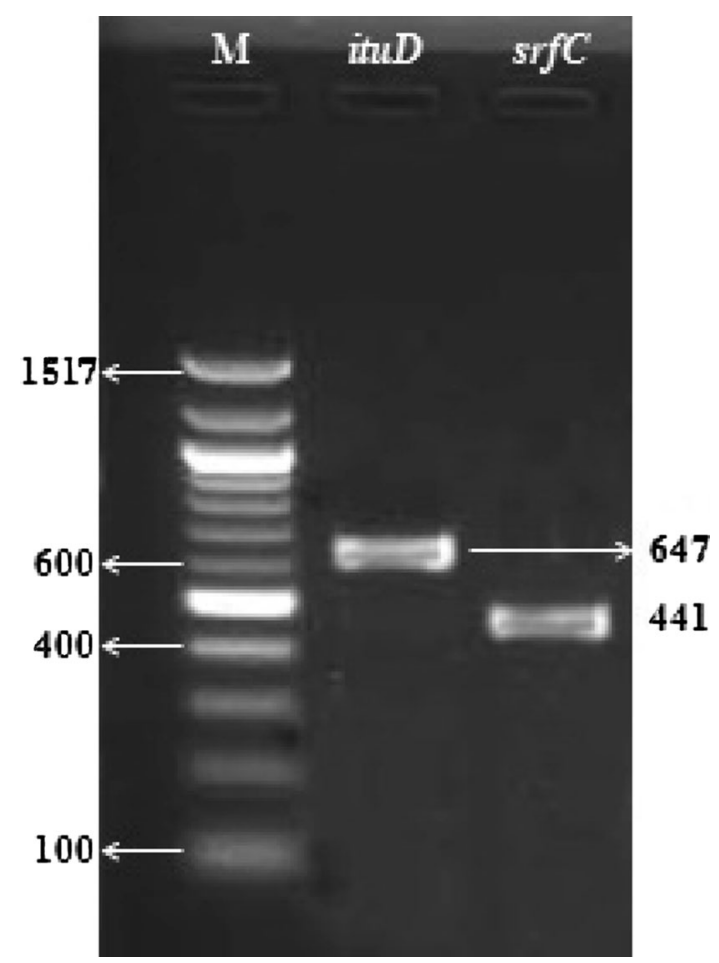

Fig. 2 PCR amplification of lipopeptide genes shows the presence of $i t u D$ and $s r f C$ gene in native isolate YSPMK11 ( $M 100$ bp molecular weight marker)

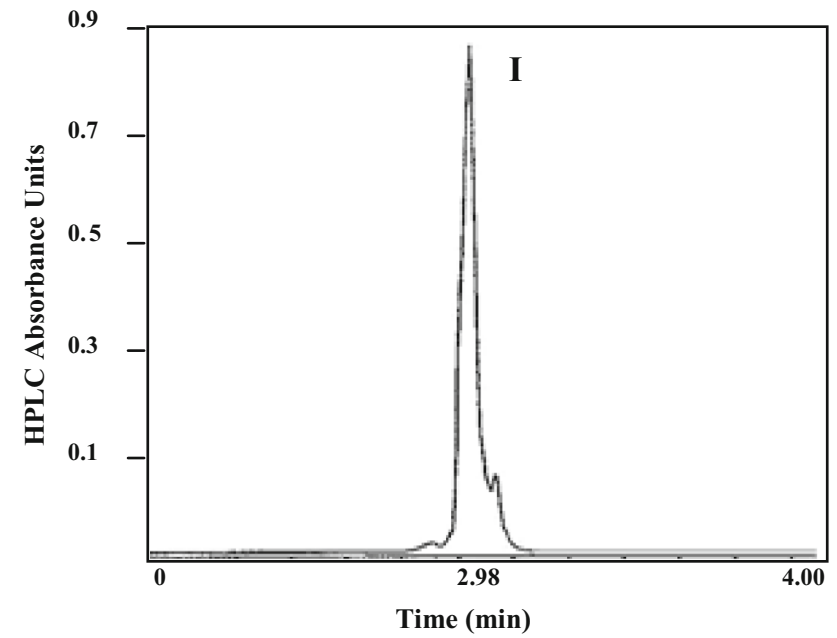

Fig. 3 GC spectrum of identified compound from B. pumilus extract

\section{Detection of lipopeptide genes}

The isolate YSPMK11 was further subjected to detect the presence of lipopeptide genes, i.e., ItuD and $\operatorname{SrfC}$ at molecular level. Results of PCR amplification showed the presence of 647 and 441 bp DNA fragments which confirmed the presence of $I t u D$ and $S r f C$ genes, respectively, in this isolate (Fig. 2). 
Fig. 4 Antifungal activitydual culture test (by extracted lipopeptides). a Sclerotinia sclerotiorum positive control with methanol. b Sclerotinia sclerotiorum growth inhibition by extracted lipopeptides (iturin A)
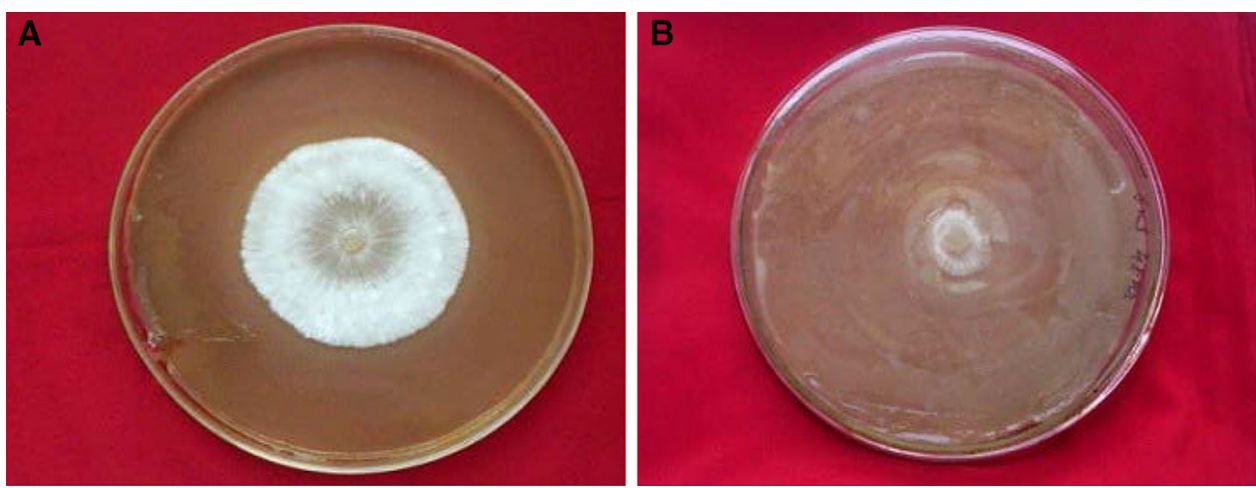

Table 5 Control of Sclerotinia stalk rot \pm standard deviation by rhizobacterial strain YSPMK11 of Bacillus

\begin{tabular}{llll}
\hline Treatments & $\begin{array}{l}\text { Disease incidence } \\
(\%)\end{array}$ & $\begin{array}{l}\text { Disease severity } \\
(\%)\end{array}$ & $\begin{array}{l}\text { Control efficacy } \\
(\%)\end{array}$ \\
\hline $\mathrm{T}_{1}$ & $6.03 \pm 0.32$ & $9.23 \pm 0.20$ & $29.83 \pm 1.63$ \\
$\mathrm{~T}_{2}$ & $1.96 \pm 0.12$ & $0.77 \pm 0.01$ & $93.13 \pm 0.41$ \\
$\mathrm{~T}_{3}$ & $1.83 \pm 0.31$ & $0.73 \pm 0.009$ & $93.70 \pm 1.09$ \\
$\mathrm{~T}_{4}$ & $2.00 \pm 0.30$ & $0.89 \pm 0.03$ & $92.60 \pm 1.25$ \\
$\mathrm{~T}_{5}$ & $2.86 \pm 0.17$ & $1.26 \pm 0.31$ & $89.46 \pm 0.42$ \\
$\mathrm{~T}_{6}$ & $2.93 \pm 0.37$ & $1.27 \pm 0.28$ & $86.86 \pm 3.20$ \\
$\mathrm{~T}_{7}$ & $2.96 \pm 0.21$ & $1.47 \pm 0.37$ & $86.03 \pm 2.51$ \\
$\mathrm{~T}_{8}$ & $2.46 \pm 0.23$ & $1.41 \pm 0.36$ & $89.03 \pm 3.48$ \\
$\mathrm{~T}_{9}$ & $2.46 \pm 0.31$ & $1.32 \pm 0.24$ & $88.76 \pm 2.46$ \\
$\mathrm{~T}_{10}$ & $2.70 \pm 0.32$ & $1.48 \pm 0.27$ & $87.16 \pm 2.77$ \\
$\mathrm{CD}$ & 0.806 & 0.608 & 6.582
\end{tabular}

Values are the mean of quadruplicate trials conducted at two places

\section{Identification of antifungal compounds}

The culture filtrate fraction was analyzed by GC-MS and there was only one potential antifungal compounds detected.

The retention time of this metabolite was $2.98 \mathrm{~min}$ and designated as I (Fig. 3). The potential antifungal substance was identified as iturin A as major components of fraction.

\section{Bioassay of lipopeptide (iturin A)}

Methanol extract $(100 \mu \mathrm{l})$ was bioassayed on MEA plates which displayed $82.6 \%$ mycelial growth inhibition of $S$. sclerotiorum (Fig. 4).

\section{Field evaluation of $B$. pumilus strain YSPMK11 as biocontrol agent}

SSR incidence and severity greatly reduced with use of microbial control agent (B. pumilus strain YSPMK11) as compared to control and regularly employed fungicide.

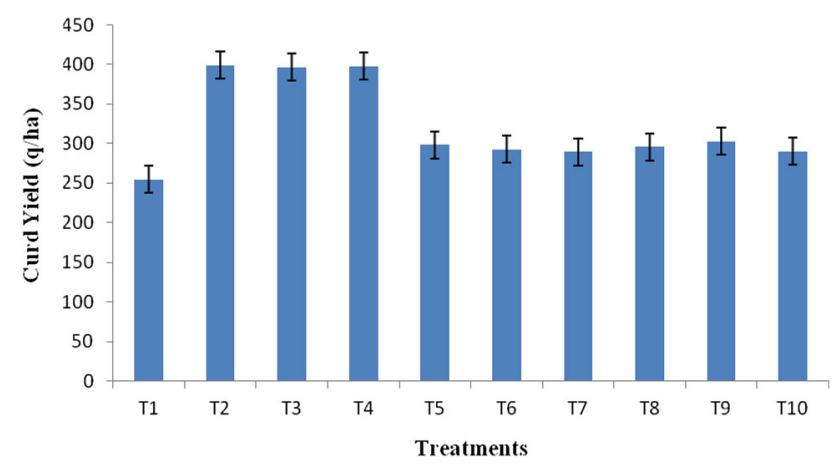

Fig. 5 Effect of bioinoculation of native isolate YSPMK11 and fungicides on curd yield of cauliflower

Results showed that before 7 days of harvesting the crop, incidence and severity of SSR in uninoculated control plots were 6.03 and $9.23 \%$, respectively, while those having fungicide treatment ranged from 2.46 to $2.96 \%$ (incidence) and $1.26-1.48 \%$ (severity). However, plots received bioinoculation of $B$. pumilus strain YSPMK11 had incidence and severity of SSR of 1.96 and $0.77 \%$ (50\% bloom), 1.83 and $0.73 \%$ (30 and 50\% bloom), and 2.00 and $0.89 \%$ (30\% bloom), respectively. Bioinoculated plots also observed reduced incidence and severity by $92.60-93.70 \%$, respectively, at 30 and $50 \%$ bloom stages suggesting that B. pumilus strain YSPMK11 exhibited better disease control efficacy over the commercially available fungicides (86.03-89.46\%) (Table 5). Thus, bioinoculation of $B$. pumilus strain YSPMK11 at 30 and $50 \%$ bloom stages exhibited maximum (93.70\%) control efficacy. Curd yield was increased by all three applied treatments (having bioinoculation of $B$. pumilus strain YSPMK11) over uninoculated controls with highest $(398.8 \mathrm{q} / \mathrm{ha})$ recorded of $\mathrm{T}_{2}$ which was significantly at par with $\mathrm{T}_{3}(396.4 \mathrm{q} / \mathrm{ha})$ and $\mathrm{T}_{4}$ (397.4 q/ha) (Fig. 5). However, cauliflower yield increased by $36 \%$ with $B$. pumilus strain YSPMK11 $\left(\mathrm{T}_{2}-\right.$ $\mathrm{T}_{4}$ ) compared to uninoculated control $\left(\mathrm{T}_{1}\right)$. When compared to other fungicide treatments, yield was 24-27\% greater with the use of B. pumilus strain YSPMK11. 


\section{Discussion}

In the present study, strain YSPMK11 was isolated from cauliflower endorhizosphere and evaluated its potential against $S$. sclerotiorum in vitro and in vivo. Solubilization of insoluble TCP by the strain YSPMK11 was associated with a decline in $\mathrm{pH}$ value. In our study, strain YSPMK11 was found as the best solubilizer of inorganic phosphates due to the production of organic acid, which is considered to be the chief mechanism of $\mathrm{P}$ solubilization (Sanjotha et al. 2011). Higher concentration of IAA was produced in the presence of $3 \mathrm{mg} / \mathrm{ml}$ tryptophan which is directly correlated with growth promotion of plants. $\mathrm{HCN}$ and siderophore production by isolate YSPMK11 proves its plant growth promoting properties and antagonistic nature against $S$. sclerotiorum. When subjected to test antagonism against $S$. sclerotiorum, zone formation was observed by isolate YSPMK11 which may be due to secretion of antifungal substance that strongly inhibited radial growth of phytopathogenic fungi on agar. Isolate YSPMK11 also exhibited excellent control efficacy because of their ability to form endospores and the broad-spectrum activity of their antimicrobial compounds. The maximum antifungal metabolite produced by isolate YSPMK11 in culture filtrate was observed after $72 \mathrm{~h}$ of incubation at $35{ }^{\circ} \mathrm{C}$ and at pH 7 in nutrient broth (Tables 1, 2, 3, 4). The physical factors that have been reported to affect antimicrobial metabolite production are temperature (Shanahan et al. 1992) and pH (Ownley et al. 1992). Isolate YSPMK11 was further subjected to molecular analysis. 16S rRNA sequence was highly homologous to $B$. pumilus. The PCR analysis further confirms the presence of ItuD and SrfC lipopeptide genes in isolate YSPMK11 which were responsible for the antifungal activities. Iturin $\mathrm{A}$ has reported to have strong haemolytic activity which kills wide range of fungal phytopathogens, whereas surfactin help in swarming, cell spreading, and biofilm production which favours the bacteria to colonize the root cells of plants (Moran et al. 2009; Yuan et al. 2011). In this study, we also found the potential antifungal compounds produced by $B$. pumilus. It suggested that a greater proportion of the fraction containing iturin A was responsible for the antifungal activities which result into inhibit the growth of S. sclerotiorum.

In the present study, versatile test isolate $B$. pumilus strain YSPMK11 showed noticeable attributes under in vitro conditions; therefore, this isolate was examined as a biocontrol agent in cauliflower against SSR caused by $S$. sclerotiorum under field conditions. Application of $B$. pumilus strain YSPMK11 was highly effective over the 2 year experimentation. Twice application of $B$. pumilus strain YSPMK11 $\left(9 \times 10^{8} \mathrm{CFU} / \mathrm{ml}\right)$ at 30 and $50 \%$ bloom stage controlled disease incidence $(93.70 \%)$ of SSR in cauliflower, higher than that of commercially available and regularly practiced fungicides in farmers field at various agroclimatic locations of Himachal Pradesh. In another study, disease severity was greatly reduced by $B$. subtilis strain SB24 when applied the cell suspension, broth culture, or cell-free filtrate solution $24 \mathrm{~h}$ before inoculation with S. Sclerotiorum displayed significant effect (Zhang and Xue 2010). Liu et al. (2010) demonstrated better control of S. sclerotiorum by cell-free filtrate of endophytic bacteria Yc8 application on the rapeseed leaves $24 \mathrm{~h}$ before fungal inoculation. Under field conditions, Bacillus isolate has a potential to be used as biobacteriocide in tomato plants (Santiago et al. 2015) and for the control of red rot in sugarcane (Hassan et al. 2015). However, the presence of biologically active metabolite produced by the antagonist, which diffused in the agar media, can be indicated by the zone of inhibition seen in the dual culture plates. Although our in vitro data indicate that isolate YSPMK11 inhibits $S$. sclerotiorum by means of antibiosis (Kumar and Kaushik 2013). Increase in curd yield by $36 \%$ over control may be attributed to the ability of bacteria to make $\mathrm{P}$ assimilable, and simultaneously produce plant growth promoting substances. This suggests that increasing crop production in sustainable manner by bioinoculation with the addition of small amount of insoluble inorganic $\mathrm{P}$ can be used as a feasible alternative of chemical fertilizers/fungicides.

It is thus concluded that application of B. pumilus strain YSPMK11 showed the better yield of cauliflower plants through reducing the percent disease incidence of S. sclerotiorum in infested plants. The presence of surfactin and iturin antifungal compound in this isolate makes it potent strain for biological control application in agriculture. This is the first study which showed that B. pumilus strain YSPMK11 has tremendous potential to be used as effective biocontrol agent against SSR in cauliflower and, therefore, deserved to be further developed.

Acknowledgements Authors thanks to ICAR, New Delhi for financial support provided to carry out this study.

\section{Compliance with ethical standards}

Conflict of interest Authors declare no conflict of interest.

\section{References}

Anonymous (2000) Pesticide-guidelines for the field efficacy trials (I). National Standards of China, Standards Press of China

Awais M, Pervez A, Qayyum S, Saleem M (2008) Effects of glucose, incubation period and $\mathrm{pH}$ on the production of peptide antibiotics by Bacillus pumilus. Afr J Microbiol Res 2:114-119

Bakker AW, Schippers B (1987) Microbial cyanide production in the rhizosphere to potato yield reduction and Pseudomonas spp. 
mediated plant growth stimulation. Soil Biol Biochem 19:451-457

Bolton MD, Thomma BPHJ, Nelson BD (2006) Sclerotinia sclerotiorum (Lib.) de Bary, biology and molecular traits of a cosmopolitan pathogen. Mol Plant Pathol 7:1-16

Bray RH, Kurtz LT (1945) Determination of total organic and available forms of phosphorus in soils. Soil Sci 59:39-45

Costacurta A, Mazzafera P, Rosato YB (2006) Indole-3-acetic acid biosynthesis by Xanthomonas axonopodis pv. citri is increased in the presence of plant leaf extracts. FEMS Microbiol Lett 159:215-220

Dubey RC, Maheshwari DK (2011) Practical microbiology. S. Chand and Company, New Delhi

FernandoA WGD, Nakkeeran S, Zhang Y, Savchuk S (2007) Biological control of Sclerotinia sclerotiorum (Lib.) de Bary by Pseudomonas and Bacillus species on canola petals. Crop Prot 26:100-107

Gond SK, Bergen MS, Torres MS, White JF Jr (2015) Endophytic Bacillus spp. produce antifungal lipopeptides and induce host defence gene expression in maize. Microbiol Res 172:79-87

Hassan MN, Namood-e-Sahar, Shah S, Zia-Ul-Husnain S, Afghan S, Hafeez FY (2015) Suppression of red rot disease by Bacillus sp. based biopesticide formulated in non-sterilized sugarcane filter cake. Biocontrol. doi:10.1007/s10526-015-9673-4

Hu X, Roberts DP, Xie L, Maul JE, Yu C, Li Y, Zhang S, Liao X (2013) Bacillus megaterium A6 suppresses Sclerotinia sclerotiorum on oilseed rape in the field and promotes oilseed rape growth. Crop Prot 52:151-158

Huang X, Zhang N, Yong X, Yang X, Shen Q (2012) Biocontrol of Rhizoctonia solani damping-off disease in cucumber with Bacillus pumilus SQR-N43. Microbiol Res 167:135-143

Kamal MM, Lindbeck KD, Savocchia S, Ash GJ (2015) Biological control of sclerotinia stem rot of canola using antagonistic bacteria. Plant Pathol 64:1375-1384

Kumar S, Kaushik N (2013) Endophytic fungi isolated from oil-seed crop Jatropha curcas produces oil and exhibit antifungal activity. PLoS One 8:e56202

Li H, Liu L, Zhang S, Cui W, Lv J (2012) Identification of antifungal compounds produced by Lactobacillus casei AST18. Curr Microbiol 65:156-161

Liu B, Huang LL, Buchenauer H, Kang ZS (2010) Isolation and partial characterization of an antifungal protein from the endophytic Bacillus subtilis strain EDR4. Pest Biochem Physiol 98:305-311

Meena KR, Saha D, Kumar R (2014) Isolation and partial characterization of iturin like lipopeptides (a bio-control agent) from a Bacillus subtilis strain. Int J Curr Microbiol App Sci 3:121-126
Moran S, Rai DK, Clark BR, Murphy CD (2009) Precursor-directed biosynthesis of fluorinated iturin A in Bacillus spp. Org Biomol Chem 7(4):644-646

Ownley BH, Weller DM, Thomashow LS (1992) Influence of in situ and in vitro $\mathrm{pH}$ on suppression of Gaeumannomyces graminis var. tritica by Pseudomonas fluorescens 2-79. Phytopathology 82:178-184

Pryor SW, Gibson DM, Krasnoff SB, Walker LP (2006) Identification of antifungal compounds in a biological control product using a microplate inhibition bioassay. Am Soc Agric Biol Eng 49:1643-1649

Saharan GS, Mehta N (2008) Sclerotinia diseases of crop plants, biology, ecology and disease management. Springer, The Netherlands

Sanjotha P, Mahantesh P, Patil CS (2011) Isolation and screening of efficiency of phosphate solubilizing microbes. Int J Microbiol Res 3:56-58

Santiago TR, Grabowski C, Rossato M, Romeiro RS, Mizubuti ESG (2015) Biological control of eucalyptus bacterial wilt with rhizobacteria. Biol Control 80:14-22

Schwyn B, Neilands JB (1987) Universal chemical assay for the detection and determination of siderophore. Anal Biochem 160:47-56

Shanahan P, O’Sullivan DJ, Simpson P, Glennon JD, O’Gara F (1992) Isolation of 2, 4-diacetylphloroglucinol from a fluorescent Pseudomonad and investigation of physiological parameters influencing its production. Appl Environ Microbiol 58:353-358

Wahyudi AT, Prasojo BJ, Mubarik NR (2010) Diversity of antifungal compounds-producing Bacillus spp. isolated from rhizosphere of soybean plant based on ARDRA and 16S rRNA. Hayati J Biosci $17: 145-150$

Warnock DW (1989) Methods with antifungal drugs. In: Evans EGV, Richardson MD (eds) Medical mycology—a practical approach. IEL Press, Oxford

Yexin Z, Huqiang Q, Fengjie N, Lili H, Xiaoning G, Zhensheng K, Qingmei H (2011) Investigation of Sclerotinia stem rot in Shaanxi Province. Plant Prot 2:116-119

Yuan J, Raza W, Huang Q, Shen Q (2011) Quantification of the antifungal lipopeptide iturin A by high performance liquid chromatography coupled with aqueous two phase extraction. J Chromatogr B Anal Technol Biomed Life Sci 879:2746-2750

Zhang JX, Xue AG (2010) Biocontrol of sclerotinia stem rot (Sclerotinia sclerotiorum) of soybean using novel Bacillus subtilis strain SB24 under control conditions. Plant Pathol 59:382-391 